
2008-E-11

\title{
Chile: A Pioneer in Trade Policy
}

\author{
Barbara Stalling \\ William R. Rhodes Research Professor and \\ Director of the Watson Institute for International Studies, \\ Brown University
}

June 2008

Paper presented at the International Symposium "Competitive Regionalism," Ibuka International Conference Hall, Waseda University, Tokyo, Japan. May 30 to 31, 2008. 


\section{Chile: A Pioneer in Trade Policy \\ by \\ Barbara Stallings \\ Watson Institute for International Studies, Brown University}

Chile has followed one of the most aggressive trade policies in the world over the last three decades. It has engaged in unilateral trade liberalization, supported and participated in multilateralism, and pioneered in the negotiation of bilateral and plurilateral preferential trade agreements (PTAs). ${ }^{1}$ PTA partners have included its neighbors in Latin America, but also the United States, Europe, and Asia. No partner seems too big or too powerful for the Chilean trade juggernaut, and few seem too small or too weak. As two trade experts said recently, "When it comes to trade and integration policies, Chile seems to be approaching 'the end of the story.' The pioneer of trade liberalization in Latin America and the Caribbean has probably gone far beyond any other developing country....The journey to free trade... was not without setbacks, but Chile’s trade policies these days are as close to textbook recommendations as they can get” (Mesquita Moreira and Blyde, 2006, p.3).

The questions to be answered in this chapter - as in the other country analyses in the book - are three. First, what triggered the PTA process? Second, who were the main actors, and what were the characteristics of the decision-making process? Third, what were the outcomes? The chapter is organized around these questions. Section 1 looks at the history of trade policy in Chile from the early 1970s to the present to see how and why the PTA process emerged. Section 2 addresses the three hypotheses presented in the introductory chapter as possible explanations of the PTA process. Was the process primarily an independent one, or did it respond to the actions of other countries through either emulation or competition? Section 3 explores the outcomes of the PTA process for Chile itself and for regional integration in Latin America. Section 4 concludes.

The argument about the Chilean experience with preferential trade agreements is the following. Different motives account for joining with different regional partners, but in all cases the government was the lead actor and the private sector played a fairly minor role. Chile is a small country that is isolated both geographically and politically. During the military regime

\footnotetext{
${ }^{1}$ One pair of authors speaks of Chile's "lateral” trade policy, referring to a remark by Lawrence Summers that countries should support all lateral reductions in trade barriers, whether multi-, uni-, tri-, or plurilateral (Sáez and Valdés, 1999, p. 86).
} 
from 1973 to 1989, it undertook a tremendous amount of trade liberalization on a unilateral basis and, by the late 1980s, had the strongest economic performance record in the region. With the resumption of democracy in 1990, the government looked for ways to reintegrate the country with its neighbors and began to sign bilateral and plurilateral agreements. These were not particularly important in economic terms in the short run, but they did have some interesting potential in terms of Chile's long-term strategy. The attempt to legally bind its neighbors into more liberal policies may have been a collateral goal. The agreements with the United States and Europe had defensive economic aims in the sense of locking in major markets to avoid future trade diversion. The Asian agreements were aggressive steps to try to get ahead of potential rivals and, perhaps, to obtain political recognition as a "first mover." In all of the non-Latin American partnerships, the desire to attract foreign investment has been at least as important as the interest in trade. Chile would like to be a hub for foreign investment in Latin America, but mainly to obtain the economic benefits. It is a very pragmatic country.

\section{A Brief History of Chilean Trade Policy and the Role of PTAs}

The history of Chilean trade policy can be divided into three phases, as seen in Figure 1. The first represents the phase of unilateral opening (1973-89). The second is the phase of preferential trade agreements with neighboring Latin American countries (1990s). The third is the phase of preferential agreements with non-Latin American regions (2000s). This schematic is an oversimplification since additional unilateral liberalization also occurred after 1990, but the main emphasis changed toward negotiated opening. In addition, it should be noted that the dates reflect when the agreements went into effect. Negotiations for the some of the non-Latin American PTAs were begun much earlier, while some are ongoing with Latin America as well as Asia.

At the time of the military coup against President Salvador Allende in September 1973, Chile had a typical Latin American closed economy where the state played a major role. Indeed, it was an extreme example after the three years in which Allende's Popular Unity coalition tried to move toward socialism. In the trade sphere, average tariffs were around 100 percent and sometimes exceeded 200 percent. They were reinforced by other policies, such as quantitative restrictions, multiple exchange rates, and capital controls. Exports relied heavily on copper, and trade represented less than 30 percent of GDP. 
Phase 1: Liberalizing trade, then, was one of the main reforms that the new economic team put into place, and they did it in a very dramatic way. Quantitative restrictions were quickly eliminated, and the government announced a gradual reduction of tariffs to a maximum of 60 percent for 1977. This goal was superseded, however, by the announcement of a 10-35 percent rate for 1978. Finally, tariffs were set at a uniform rate of 10 percent in 1979. While exchange rate policy was supposed to compensate for the rapidly falling tariffs, a real appreciation set in after an initial devaluation, as shown in Figure 1. In 1979, the rate was pegged against the dollar. Not surprisingly, the trade deficit burgeoned.

The trade deficit, together with financial imbalances and international shocks, led to a serious balance-of-payments crisis in the early 1980s. In addition to devaluing the currency, the flat tariff rate was raised to 35 percent for a brief period of time with even higher rates for a few individual products. Unlike some of its neighbors, the Chilean military survived the crisis, a more pragmatic economic team was installed, and tariffs were again lowered to reach a uniform 15 percent rate by 1988. The impact of these various changes on exports was predictable. After an initial surge, they fell to reach a trough in 1981, but then expanded by almost 20 percentage points of GDP between 1981 and the later part of the decade (see Figures 2a and b).

Phase 2: A democratic government returned to Chile in 1990. To the surprise of many, the basic elements of the earlier reforms, including the trade liberalization, were maintained and even deepened. Thus, in 1991 tariffs were reduced across the board from 15 to 11 percent, and in 1998 the Congress approved a further five-point reduction over a five-year period. At the same time, important adjustments were made both to domestic and international policies. With respect to the latter, one of the most controversial changes was the decision to initiate negotiations for a set of preferential trade agreements (Silva, 2004)

This change came about for several reasons as the new government looked at the world in 1990. First, it was becoming clear that international trade was going to be a key driver of economic growth. Second, at the same time, the multilateral trade negotiations of the Uruguay Round were not going very well. Third, partly as a consequence, both the United States and Europe were looking toward bilateral or plurilateral agreements to improve their trade access. In the light of this scenario, the question for the Chilean government was now to best move forward with the export model developed in the previous years. 
The Alywin administration (1990-94) argued that unilateral liberalization and preferential trade agreements are complements, not substitutes. Two main economic roles would be fulfilled by PTAs. First, they would bring about some amount of opening on the part of trade partners. By definition, unilateral liberalization affects only the policies of the country itself, and while it may make exports more competitive, it does not open markets. Second, they would lower transaction costs by providing rules to increase stability, promote transparency, and ensure fulfillment of commitments. In principle, multilateral agreements would serve these functions better than bilateral PTAs, but the length of time taken by these negotiations and the compromises required to obtain support for treaties led many countries to seek alternatives (Sáez and Valdés, 1999). In addition to these economic motives for beginning to negotiate preferential agreements, political motives were at least as important. They included the reintegration of Chile into the regional and international system, international recognition of Chile as an important player, and support for governments with a similar political-economic stance.

Mainstream economists and the right-wing political opposition in Chile opposed the new policy initiative, seeing bilateralism as a distinct second-best to unilateral liberalization. They pointed out that the effect of signing a number of bilateral agreements would be to replace the uniform tariff with a range of differentiated rates. They were also concerned that bilateral agreements would reduce the likelihood of multilateral liberalization through the GATT/WTO. This opposition was overcome, in part, by continuing the unilateral tariff reduction at the same time the PTAs were being negotiated (Sáez and Valdés, 1999).

Given the decision to expand Chile's trade policy instruments to include preferential agreements, the question was with whom to negotiate. Table 1 shows the list of Chilean trade agreements through 2007 and some characteristics of each. The first partners were in Latin America although, as will be explained later, disagreement existed within the government on whether Latin America should have been at the head of the queue. Nonetheless, agreements were signed with ten Latin American countries between 1992 and 1998. They included Mexico in 1992, Bolivia and Venezuela in 1993, Colombia in 1994, Ecuador in 1995, the four countries of Mercosur (Argentina, Brazil, Paraguay, and Uruguay) in 1996, and Peru in 1998. These agreements were so-called Economic Complementation Agreements (ECAs), which were negotiated within the framework of the Latin American Integration Association (ALADI, by its Spanish acronym). 
The ALADI framework is very flexible, ${ }^{2}$ but the agreements tend to be narrow (focused mainly on trade in goods) and lacking in rigor (obligations are not defined in a precise way). The ECAs contrast with the so-called FTA model that came into being with NAFTA. The latter is both broader and more specific. Rules for trade in goods are much more demanding, especially with respect to rules of origin. They also include many other issues, such as services, investment, and dispute settlement mechanisms. ${ }^{3}$ The Chile-Mexico ECA was upgraded to an FTA in 1998, and the Colombia and Peruvian accords are in the process of upgrading. The Mercosur agreement, also negotiated under ALADI, involved political as well as economic elements, as will be discussed below.

While the spotlight was on negotiating agreements with Latin America, under the surface another set of relationships was being developed simultaneously. In 1991, Chile was the first Latin American country to respond positively to President Bush's Enterprise for the Americas Initiative (Rosales, 2003). Discussions began for an FTA under President Clinton, but were held up by the NAFTA controversy and the elimination of presidential authority to get trade agreements through congress ("fast track," later "trade promotion authority"). In the meantime, however, an important intermediate step was taken through an FTA between Chile and Canada, signed in 1996. It established many of the parameters for the FTA with the United States, especially with respect to services and investment. Other items, such as intellectual property and technical standards, were not included since it was considered that WTO rules, plus the two countries' own legislation, dealt with these matters satisfactorily. Environmental and labor accords were incorporated as side agreements, as had been done with NAFTA.

Phase 3: In the current decade, Chile took a major step forward and began to sign agreements with its biggest trading partners. The initial ones were with the traditional partners Europe and the United States - but soon agreements were being made with Asian countries that had become important export markets and import providers. In general, the agreements were broad ones that fit into the category of the new FTA-type trade model.

The first of the new set of agreements to be ratified was an Economic Association Agreement with the European Union. It included goods, services, and government procurement

\footnotetext{
${ }^{2}$ One reason for the flexibility was that the congress did not have to approve agreements signed under the ALADI umbrella. Nonetheless, the executive branch agreed to take the proposed Mercosur agreement to the congress because of its controversial nature.

${ }^{3}$ See discussion of the two models in Sáez (2005). Stoler (2006) discusses some of the same issues with respect to agreements in Asia.
} 
as well as liberalization of investment and capital flows, the protection of intellectual property rights, and a binding dispute settlement mechanism. Indeed, the EU called it "the most innovative and ambitious results ever negotiated by the EU” with respect to trade. ${ }^{4}$ In addition, it covered many other issues including political dialogue (security and related issues) as well as cooperation on industry, science and technology, culture and education, migration, drugs, and so on.

The long-awaited treaty with the United States was not signed until June 2003, nearly 12 years after the idea had first been mooted. It built on the Canada-Chile and NAFTA treaties, but added new dimensions. It covered seven general areas: market access, trade remedies, customs rules and standards, services, investment, labor, and the environment. The most controversial issue was the inclusion of labor and environmental provisions within the treaty itself. Chile had hoped to have them incorporated as parallel agreements as had been the case with NAFTA and the Canada agreement, but the political reality in the United States made this impossible. Also controversial were Chile’s capital controls, designed to avoid short-term speculative flows. Eventually, a compromise was reached that allowed both sides to save face (Hornbeck, 2003; Rosales, 2003).

Most relevant for this book are the trade agreements negotiated with Asian economies. Thus far, Chile has signed agreements with seven Asian countries (Korea, Singapore, New Zealand, Brunei, China, India, and Japan). Three others are under active negotiation (Australia, Malaysia, and Thailand), and several others are under discussion. With the exception of the China and India treaties, all are broad, detailed agreements of the FTA type. ${ }^{5}$

The first Asia-Latin America FTA was signed by Chile and Korea in February of 2003. It was controversial on both sides because of fears by Korean farmers and Chilean industrialists. The terms with respect to goods were broad; investment and services were also included although with exceptions. The next Asian accord was signed in mid-2005 by the so-called P-4 group, which was constituted by four small economies: Chile, Singapore, New Zealand, and Brunei. Not surprisingly, this was one of Chile's most complete agreements since both Singapore

\footnotetext{
${ }^{4}$ EU website: http://ec.europa.eu/trade/issues/bilateral/countries/chile/index en.htm (accessed 11/29/07).

${ }^{5}$ Stoler (2006) discusses the concept of "high-quality" agreements in the Asian context. He reports that APEC members have developed best-practice guidelines. These include WTO consistency (substantially all trade barriers removed within reasonable period as well as comprehensiveness). Other criteria deal with WTO Plus commitments: transparency, trade facilitation, simplified rules of origin, cooperation, sustainable development, and accession by third parties.
} 
and New Zealand have very open economies. The coverage was broad, and specific reference was made to the agreement as a model for free trade in the Asian region (Stoler, 2006). It also has an accession clause so that others can join.

The agreements with China (2005) and especially India (2006) were less inclusive. Both were limited to goods, although the China treaty anticipated future negotiations on services and investment; a technical agreement has already been reached. The China agreement provided immediate duty-free entry for the vast majority of Chile's exports, but some of the most interesting for Chile (fruits and fish) were put on the 10-year list. A dispute mechanism was included together intellectual property and various social topics. The India agreement was much more limited, involving reduction in average tariffs of between 10 and 50 percent on a list of products (Rosales and Kuwayama, 2007).

The final Asian agreement has been concluded with Japan, which was Chile’s initial trade and investment partner across the Pacific. While the agreement was broad - including services, public purchasing, and phytosanitary measures - the trade access measures favored Japan more than Chile. More than 70 percent of Chilean exports will enter duty-free immediately, but over 90 percent of Japanese exports will get immediate access. In signing the agreement, the Chilean government emphasized the importance of the Asian accords for Chile's role as an intermediary between the two regions.

\section{Explanations for Chilean PTAs}

This book aims to "test” three hypotheses that might explain a country’s PTA strategy independent decision making (the null hypothesis), emulation of leading countries, or competition of economic, political, and/or legal types. The argument here is that Chile does not fit neatly into any of the three. Perhaps not surprisingly, since the country has been signing PTAs for nearly two decades, there have been shifts in motivation over time and among partners, and the agreements have included aspects of all three hypothesized models.

Insofar as competition is important, we need to answer two main questions: competition with whom and with respect to what? Three competitors, or groups of competitors, might be relevant for Chile. First is a single country - Mexico - which is also Chile's most important ally in the region. Among Latin American countries, only Mexico can match Chile's performance record. Chile has frequently followed Mexico's lead, for example in the agreements with the 
United States, Europe, and Japan. Of course Mexico has a great advantage with its geographical location on the U.S. border, and many partners are interested in agreements with Mexico to gain an entrée to the United States. Also Mexico is much larger than Chile, which is another advantage. Nevertheless, Chile has kept up and, especially in Asia, surpassed its northern friend and rival.

A second set of competitors are other South American countries. Brazil is one of the world's giants, which are of interest to all economic players. It also leads an integration group, Mercosur, which includes nearly 300 million consumers (compared to Chile's population of 16 million). But Brazil, another close Chilean ally, has an economy that is basically complementary to Chile's. The same is not true of Argentina, also a member of Mercosur. Argentina competes with Chile in many important products - and has not always been a friend. Finally, other emerging market countries, especially those in Asia, are potential competitors in the Asian region itself.

The issue of competition also involves the question of competition over what. In economic terms, competition is focused on trade and investment. An important part of Chile's current basket of export products, the 40-odd percent that consists of copper, does not face a competitive threat, since Chile is the world's largest and most efficient producer. More important is competition for agricultural and agro-industrial products together with services at the present and high-tech industrial products for the future. Competition over foreign direct investment is perhaps of greater interest to Chile than competition over export markets. Chile wants FDI in its industrial sector both for the resulting access to technology and the access to markets.

In addition to these economic types of competition, and closely related to them, is a political-economic goal. Chile is clearly interested in positioning itself as the hub for South America's relationships with as much of the rest of the world as possible. This goal holds for both the trade and investment realms and in physical infrastructure as well. The agreements with Latin American neighbors, especially Mercosur, are crucial prerequisites for this plan. What Chile has to offer international partners is its political and economic stability, its good policies, and its openness. It is interesting that this approach is fairly similar to what Mexico is trying to do in the northern part of the hemisphere.

Latin American PTAs: In 1990, with the return of a democratic government and the decision to expand trade policy to include bilateral and plurilateral agreements, two different sets 
of partners and approaches were proposed by different ministries of the Chilean government. The Ministry of Foreign Affairs wanted to use PTAs as an instrument for reintegrating Chile into the Latin American region after 17 years of near isolation under the military regime. Many in the Foreign Ministry saw Latin American regional integration as part of a political project, such as that developing in Europe; it would also provide the structure for joint negotiations with the industrial countries and thus greater leverage. This model represented an independent top-down strategy initiated by government officials, whose economic advantages were still far in the future. Chile's main economic links at the time were with the industrial countries. In 1990, approximately 65 percent of Chilean exports were sold to the United States, the European Union, and Japan (calculated from IMF, 1991). Moreover the vast majority of its foreign capital came from those same countries. Data on the stock of FDI in 1990 showed that 60 percent was from the United States and Canada, 27 percent from Europe, and 3 percent from $\operatorname{Japan}^{6}$ (IRELA, 1996). Latin America, by contrast, represented only 13 percent of export sales and 3 percent of capital stock.

In light of this economic structure, the Ministry of Finance advocated negotiation with the United States as the top priority. This option might be regarded as an emulation approach whereby Chile would follow U.S. trade policy as manifested in agreements with Israel (1985), Canada (1988), and Mexico (begun in 1990). Indeed, Chile hoped to become the fourth member of the North American Free Trade Association (NAFTA), which would solidify its reputation as being on the leading edge among developing nations. Technical studies were begun to pave the way for an eventual negotiation process, and Chile was invited to join NAFTA at the hemispheric summit in Miami in 1994. The majority of the business sector also preferred this strategy, seeing it as opening many more opportunities than an approach focused on neighbors considered to be of dubious reliability. The process was cut short, however, by political problems that the Clinton administration encountered in getting the three-member NAFTA agreement approved. Thus external circumstances determined that Chile’s first decade of PTAs would follow the Ministry of Foreign Affairs model.

The first agreement was with Mexico with which almost no economic links existed (0.4 percent of exports and 0.1 percent of investment stock). Mexico was, however, an attractive partner for several reasons. It was a likeminded country in the sense that it was the only other

\footnotetext{
${ }^{6}$ Excludes investment from off-shore centers.
} 
Latin American nation that was not a member of a sub-regional group. It was also the country in the hemisphere, which - together with Chile - had made the most progress in market-based economic reforms, especially under the government of Carlos Salinas (1988-1994). Moreover, Mexico was negotiating a free trade agreement with the United States, and a deal with Mexico could improve Chile's own chances. ${ }^{7}$ While the Chilean business sector expressed doubts about the benefits of the proposed agreement, the will of the two presidents prevailed. An Economic Complementation Agreement between the two countries was signed in September 1991 and took effect in January 1992; it was upgraded to an FTA in 1998.

The next countries that Chile approached were its former partners in the Andean Community: Bolivia, Venezuela, Colombia, and Ecuador. These countries were small in economic terms, together accounting for only 3 percent of Chilean exports. Nor was there much likelihood of their becoming major partners in the foreseeable future. Nonetheless, all had reformist governments in the early 1990s, and agreements with them could help reinforce their inclinations in this policy direction. They would also indicate that Chile wanted to return to the neighborhood after its absence during the period of military rule, which included its exit from the Andean integration group because of the latter’s protectionist policies. And, perhaps most importantly from the point of view of the Foreign Ministry, agreements would help to resolve old political disputes and resentments. As in the case of Mexico, the business community was not enthusiastic about the Andean agreements, arguing that they did not bring much economic benefit. At the same time, the Bolivian negotiation process witnessed an important fissure among business groups. To appease the traditional agricultural sector in Chile, a narrow agreement was concluded that excluded their most sensitive products, while the industrialists thought only a broad agreement was worthwhile. ECAs with these four countries were signed in 1993 and 1994, but the internal disagreements in Chile lingered on. A few years later, Chile signed an agreement with Peru, the other Andean Community member and Chile's largest trade partner in the group. Similar business sentiment emerged, opposing agreements that were seen as more political than economic, but the government prevailed (Porras, 2003).

It was not until the middle of the decade that Chile became associated with its largest and most powerful neighbors - Argentina and Brazil - plus their smaller partners in the Southern

\footnotetext{
${ }^{7}$ Flores-Quiroga, in the paper on Mexico for this project, refers to Chile as Mexico’s “ideal first partner” in Latin America.
} 
Common Market (Mercosur). Together, in 1995, the Mercosur countries accounted for 10.7 percent of Chile's exports ${ }^{8}$ and provided about 3 percent of its investment. From the Chilean government's perspective, Mercosur was complicated for several reasons in comparison to the Andean Community. First, from an economic point of view, Mercosur had a high common external tariff and differentiated internal tariffs by products. Embracing these policies would go against Chile's lower, flat rate. Second, in political terms, the Mercosur posture was that all negotiations with other countries or groups would be done by the group as a whole. Third, unlike other integration groups in Latin America, Mercosur's goal was to work toward a political community, which would move well beyond trade and investment issues. Thus, when first approached to become part of the group at its founding in 1991, Chile declined. In 1996, however, it agreed to become an associate member.

The internal dynamic in Chile leading up to the association agreement was different than occurred with most of the other agreements that Chile signed before (and afterwards) since civil society groups played an especially active role. Indeed, the Mercosur agreement was perhaps the most controversial that Chile has ever signed. Government arguments in favor of accession mainly stressed the economic reasons for the deal, both proactive (long-term prospects for trade and investment in a large market) and defensive (Mercosur's threat to end existing preferences that were important for neighboring Chile). These views were shared by the industrial sector, which saw Argentina and Brazil as a significant market. Moreover, these two countries were the recipients of a large part of the new Chilean investments abroad. The traditional agriculture sector, however, felt extremely threatened since the Mercosur countries were among the world's most efficient producers of wheat, sugar, and vegetable oils, which were also their main products. The agriculturalists, and their association the National Agricultural Association (SNA, by its Spanish acronym), joined forces with politicians representing their districts and threatened to defeat the government's proposal. Only when the government promised payments to the affected groups, amounting to 3 percent of the 1999 budget, was the agreement was approved (Stefoni and Fuentes, 1998; Aninat, Londregan, Navia, and Vial, 2004). ${ }^{9}$

\footnotetext{
${ }^{8}$ This amount was down sharply due to slumps in Argentina and Brazil.

${ }^{9}$ The exact definition of "1999 budget" is unclear, but the amount involved is likely to have ranged between $\$ 200$ and $\$ 400$ million. While this seems like a large amount, it pales before the Korean government's offer to pay its farmers $\$ 80$ billion over 10 years as compensation for the Chile-Korea agreement.
} 
In summary, Chile's early trade agreements were with its regional neighbors. The explanations were mainly political: a way of reintegrating with the region and helping to damp down old quarrels. Even if the dominant explanation for these early agreements was political, however, several economic factors should also be noted. First, Chile, like other Latin American countries, exports higher value-added goods to the region than to most of its partners in the industrial countries. Thus, the reciprocal lowering of protection in the Latin American markets opened the way for these higher-quality exports, which could later be exported elsewhere. Second, Chile has engaged in significant outward investment, and almost all of that has been within Latin America. While the ECA arrangements did not deal with investment, in some cases they paved the way for broader modified agreements. Finally, Chile aims to become an investment hub, especially for FDI from Asia, and the regional agreements will be crucial in this regard, especially the one with Mercosur as Latin America's biggest market.

U.S. and European PTAs: If Chile's early trade agreements with its Latin American neighbors were independent decisions mainly designed to boost foreign policy goals, the next group of agreements centered on competition dynamics but had aspects of emulation as well. These agreements returned to the path that the Finance Ministry had wanted to follow earlier in negotiating with countries that were Chile's main economic partners and where it was thought that market access needed to be safeguarded from potential rivals. But, in addition, these were also political and ideological partners that Chile admired and wanted to be associated with. The United States and Western Europe were the world's leading democracies, and they were also the world's most developed economies. Being associated with them in trade agreements would enhance Chile's reputation in ways that went beyond purely economic gains.

Virtually all analyses of Chilean trade policy emphasize the national consensus that Chile has done well as a trader and must continue down this path. There is also general agreement that the country must deepen its export strategy by expanding the quantity of its sales abroad, raising their quality in terms of value added, and trying to link exports more closely to GDP growth. A look at Table 2, which compares Chile and its main trading partners on a number of characteristics, provides some understanding of the support for export-led growth. It reveals that Chile stands out in only two ways: its small size, both in population and aggregate GDP, and the importance of exports as a source of demand. Thus, once its immediate political requirements in 
the region had been taken care of through the preferential agreements discussed above, the government turned more specifically to its economic requirements.

As of the year 2000, Chile's eight largest markets, comprising 75 percent of total exports, included the European Union (24 percent), the United States (17), Japan (13), China (5), Brazil (5), Mexico (4), Korea (4), and Argentina (3). Chile already had agreements with Brazil, Mexico, and Argentina. Within seven years, it would have PTAs with the remaining five (plus several others). Economic competition was involved in these new agreements with respect to both trade and investment. Trade competition was divided between increasing markets for existing exports and opening space for new ones, especially high-technology products that the country hoped to move into. Competition for investment was an equally important goal, especially investment in industry and, in particular, high-technology products. ${ }^{10}$ Competition for new investment was mainly with other Latin American countries, while that for new trade opportunities was with emerging market economies in Asia as well as some in Latin America.

Chile's trade goals in the U.S. and EU agreements were mainly defensive - to safeguard access to its largest markets and to prevent others getting better access through preferential arrangements. With respect to the United States, Mexico - and potentially Central America and the Caribbean - were of concern to Chile, especially in terms of the industrial goods that Chile hoped to emphasize in the future. Chile’s natural resource exports already entered the United States with very low tariffs, but the policy of tariff escalation for goods with higher value added made it difficult to compete in the industrial sector. Mexico had already become a member of NAFTA, which guaranteed its access to U.S. markets, and it was possible that its smaller neighbors would also sign agreements with the United States. In the case of the EU, the main concern was with respect to the former Soviet bloc countries, many of which had become candidates for EU membership. Chile hoped to expand its traditional political links with Europe into a stronger economic partnership.

If Chile's trade goals were mainly defensive, its investment goals had a more proactive character. Chile wanted to gain access to foreign direct investment from the United States and Europe to upgrade its exports, but it also wanted to become the investment hub for South America by promoting itself as the most reliable partner in the region. Through the combination,

\footnotetext{
${ }^{10}$ Chilean officials still remember their failure to capture a big investment by Intel in the 1990s, which ultimately went to Costa Rica and transformed the industrial and trade structure of that country. They are determined not to repeat this experience.
} 
the government hoped that it could recover and maintain the high growth rate it had enjoyed from the late 1980s. Indeed, from 1985 to 1997, Chile had had a nearly-Asian rate of growth (an annual average of 7.4 percent), but it fell off at the end of the 1990s as a spillover from the Asian financial crisis. Recovery of that growth rate was important for social and political as well as economic reasons.

Both the U.S. and European agreements had long gestations. As already noted, a U.S. agreement was on the agenda from 1990. The European agreement also dated from that same period through the signing in 1990 of a framework agreement (acuerdo marco). While this framework agreement involved many social and political topics, its trade relevance was limited and the possibilities of making progress did not seem very auspicious. Moreover, the main business opinions about the EU were initially negative, in the form of traditional agriculture and its representative, the SNA. The industrialists were not interested since almost no industrial exports were sold in Europe. Over time, however, the latter opinion began to change, especially as the possibility of a deal with the United States seemed more distant. When Europe itself became more interested in Latin America at the end of the decade, Chile stood out as a likely partner despite the fact that the EU preferred to negotiate with other blocs rather than individual countries. With the executive branch pushing hard, little opposition was found in Chile, except from the wine and fishing sectors where the Europeans made stringent demands. A compromise was reached over the former, and the latter was unable to arouse support for its complaint, so that an “Agreement of Political and Economic Association” was signed in May of 2002.

Perhaps stimulated by the closer relations between Chile and the EU, the outgoing Clinton administration suddenly invited Chile to begin negotiations for a bilateral trade agreement in January 2001. Once underway, the process was relatively straight forward since it closely followed the format and content of the Chile-Canada and (updated) Chile-Mexico agreements as well as that of NAFTA itself. The main sticking point was the labor and environmental agreements, which had to be incorporated into the agreement itself given the political situation in the United States. This prospect aroused a good deal of opposition in Chile, but was eventually seen as a small price to pay. In addition, the traditional opposition from the agricultural sector was muted since the SNA had been taken over by the large farming interests who would stand to benefit enormously from a U.S. agreement. It was signed in June 2003 and went into effect in January 2004. 
Asian PTAs: The place where Chile really displayed an aggressive competitive spirit competitive with respect to the rest of Latin America and some other developing countries - was in Asia. This was a deliberate strategy that dated back more than two decades. The earliest steps were Chilean attempts to break into the Japanese market, by far the most important in the region at that time. In the 1980s, Chile devoted enormous efforts to sell its fruit, other agricultural products, and wine in Japan. With the help of the Japanese trading companies (soga shosha), this was eventually accomplished. The Japanese greatly admired the persistence shown and became good customers. In some years in the 1990s, Japan actually surpassed the United States as the top destination of Chilean exports. It also began to invest in Chile in modest amounts (Saavedra, 1993).

Using Japan as a base, and developing serious diplomatic capacity in Asian affairs, Chile expanded its contacts into many Asian countries through its embassies and its export promotion office, Prochile. Prochile's job was to help potential exporters, including smaller firms, to move into Asia (and other regions). As an indicator of its Asian vocation, in 1994 Chile became the second Latin American country to become a member of APEC, following the accession of Mexico the previous year. The Chilean government also continued to hone the skills of its negotiators. Indeed, if reports are to be believed, Korea decided to negotiate Asia's first crossregional FTA in order to learn from the Chileans how to negotiate (Koo, 2006).

Korea was Chile's first Asian PTA partner; negotiations began at the former's request. Both sides were enthusiastic because it appeared that their economies were complementary, and each was eager to get a foothold in the other's region. Negotiations began late in December 1999, but stalled the following year and did not resume actively for three more years. In this case, unlike others in which Chile was involved, it was Korean farmers who felt threatened while Korean industrialists were eager for an agreement since they were being displaced in the Chilean market. On the Chilean side, the pattern was the opposite: fruit producers were enthusiastic while industrialists, especially in the household appliances sector, were very leery. The compromise was that apples and pears were excluded on Korea's side in return for protection for Chilean refrigerators and washing machines. In addition, to get the agreement ratified in Korea, their government had to promise up to $\$ 80$ billion in compensation if the Korean agriculture sector was damaged (Park and Koo, 2007). 
In rapid fashion, other Asian agreements followed. The next after Korea was with three smaller economies (Singapore, New Zealand, and Brunei), then with gigantic China and India, and finally with its long-time partner, Japan. Negotiations are underway with Australia, Malaysia, and Thailand, and some others are under discussion. This record greatly increased Chile's international prestige and, in particular, its reputation in Asia. While it helped to open markets, the goal was larger and more strategic. The Foreign Minister, when signing the Japan agreement, made this clear. "We began explorations in Asia some years ago. We dared to enter an extraordinarily large, diversified market, and with the implementation of the free trade agreement today - added to the accords that Chile already has with the People's Republic of China, South Korea, India and the countries of the P-4, as well as the network of treaties with other South American countries - Chile is becoming a platform for connection in the Pacific Rim" (Fischer, 2007).

\section{Impact of Chilean PTAs}

Table 3 shows the combined impact of the various preferential agreements that Chile signed in the decade and a half between 1992 and 2007. With the Japanese agreement in 2007, 87 percent of Chile's trade is carried out through preferential arrangements. The effective tariff - the amount actually paid by preferential partners, weighted by the size of their markets - is calculated to have fallen from 10.5 percent in 1992/93 to 0.8 percent in 2007. For countries that do not have an agreement with Chile, the rate is 6 percent.

Chile has signed a large number of trade agreements, but the question is whether they will translate into economic advantage, as hoped by the government. ${ }^{11}$ A number of studies have been carried out with respect to the impact of the trade accords. Studies exist for the U.S., EU, and Asian agreements. ${ }^{12}$ Most of these studies have employed computable general equilibrium (CGE) models. In general, they have found modest welfare gains for Chile with the largest gains involving the largest markets. Also, the more extensive the liberalization and the fewer the exclusions, the greater are the welfare gains.

\footnotetext{
${ }^{11}$ This is long been a problem with Latin America's top down integration process. That is, governments have been signing agreements for decades, but the private sector has not followed through (see Stallings, 2007). In the case of Chile, a variety of bilateral and regional trips and events have been organized to try to get the private sector engaged in exporting, to introduce potential buyers to Chile, and to pursue the investment that is such an important part of Chile's strategy.

${ }^{12}$ See Cabezas (2003) on the U.S. agreement; Nowak-Lehmann, Herzer, and Vollmer (2005) on the EU agreement; and Schuschny, Durán, and de Miguel (2007) on the Asian agreements. Other evaluations include Schiff (2002) and Harrison, Rutherford, and Tarr (1997, 2003).
} 
In terms of Chile's other goal - to increase inward investment flows - government data show no real progress, especially with respect to the Asian region. Japan has the largest investment stock ( $\$ 1.8$ billion), but this amounts to less than three percent of the total, and Japanese investment has fallen off substantially since around the year 2000. Investment by other potential Asian partners include China (investment stock of \$84 million) and Korea (\$40 million). Thus, Chile's main investors continue to be the United States and European economies (see Foreign Investment Committee website).

Another type of outcome of interest is regionalism and the impact of the PTAs. While this concern is usually posed with respect to a possible negative impact on multilateralism, similar questions can be asked at the regional level. As is pointed out in the introductory chapter, competitive regionalism can undermine regional integration, despite the fact that regional integration has long been an aim in Latin America. To what extent has this occurred? Chilean officials have been and remain concerned about "spaghetti (noodle) bowl” problems, and they have tried to structure their agreements in similar ways so as to make them compatible. With some frequency this aim was undermined among Latin American partners by the political goals that were pursued. In addition, the fact that some Latin American agreements are ECAs while others are FTAs exacerbates the problem. At the same time, Chile's agreements with countries in Europe and Asia could be seen - and are seen, especially by Mercosur - as undermining regional integration in Latin America itself.

From the Chilean viewpoint, the Free Trade Area of the Americas (FTAA) was designed to deal with these problems. It would have imposed the same terms on all member countries. The FTAA was initially proposed by Pres. George H.W. Bush as the Enterprise for the Americas Initiative in the late 1980s and reintroduced by Pres. Bill Clinton at the Miami Summit in 1994. The idea was to form a single free trade area to cover the entire hemisphere. Working groups were set up with the three regional organizations - the Organization of American States (OAS), the Interamerican Development Bank (IDB), and the U.N. Economic Commission for Latin America and the Caribbean (ECLAC) - as the technical secretariat, and significant progress was made. Indeed, one of the arguments heard for the increasing interest in PTAs in Asia is competition from the FTAA. ${ }^{13}$

\footnotetext{
${ }^{13}$ For analyses of the FTAA, see Schott (2001); Estevadeordal, Rodrik, Taylor, and Velasco (2004).
} 
In the last few years, however, political competition between the two largest countries in the hemisphere - the United States and Brazil - began to derail the project. More recently, the election of a number of governments openly opposed to the FTAA seems to have ended it, at least for the foreseeable future. This leaves a set of bilateral agreements with very different terms, as well as competing plurilateral groups that have different goals as well as different economic structures and terms. Without an FTAA to bring them together, the outlook for a robust regional integration in Latin America seems more distant than ever.

\section{Conclusions}

As this paper has amply demonstrated, Chile has conducted a very active trade policy over the past 35 years. Initially this policy was based exclusively on unilateral and multilateral mechanisms. In the 1990s, however, the Chilean government began one of the world's most intensive processes of negotiating preferential agreements - although it also continued to lower tariff rates on a unilateral basis and to participate in multilateral negotiations. The period since 1990 can, in turn, be divided into two sub-periods. During the first period, Chile concentrated on negotiations with its Latin American neighbors, mostly for political reasons. During the second period, Chile turned to negotiate with its largest markets: the United States, Europe, and Asia. In these latter cases, the motives have been mainly economic. Currently, 87 percent of Chilean trade is carried out under preferential arrangements, but the benefits still remain to be seen.

What can be said at this point about the three hypotheses - independent decision making, emulation, or competition - for explaining preferential agreements that the chapter is supposed to be testing? It was argued earlier that all three have been in play at different points in Chile's history of PTAs. The early period of economic complementation agreements in the Latin American region was an example of independent, state-led action geared mainly to achieve foreign policy goals. Insofar as economic aims were also involved in these agreements, they were elements of a future international strategy, not in competition with anything that had already been done in the region. The agreements with the larger economies, by contrast, did seem to be motivated by competition, both to lock in access to export markets in light of present and possible future competitors, but especially for foreign direct investment to play a key role in Chile’s own investment strategy and to further its aim to be an investment hub for South America. At the same time, it is possible to argue that some elements of an emulation process 
were also involved in the negotiations with the United States and Europe. As bulwarks of democracy as well as economic success, these countries were ones that Chile identified with and wanted to follow.

Looking at the indicators that were outlined in the introductory chapter for the competition versus the emulation models does not provide much help in distinguishing motives in the Chilean case. Emulation is supposed to involve as many agreements as possible and with relatively similar terms. Chile fits both of these characteristics. On the other hand, initiative by the government as opposed to "epistemic communities" is supposed to be related to competitive strategies. This characterization fits the Chilean case too, as does the outcome of fragmented regionalism. Perhaps it is the indicators themselves that are confusing, not really giving us a good handle on the differences between competition versus emulation or of independent decision making as an alternative.

A final question that can be asked in these concluding remarks is what other countries, including those from Asia, can learn from the Chilean experience with trade policy in general and preferential agreements in particular. Five such lessons suggest themselves. First, small countries can be very proactive. Perhaps it should be said that they have to be. Much of the literature on small European economies suggests as much. In this sense, Chile bears some resemblance to Singapore in the Asian context.

Second, Chile's experience shows that initial conditions are crucial. The fact that Chile began to negotiate PTAs with a flat tariff rate of 15 percent made an enormous difference in what it sought and was willing to accept. During the previous decade and a half of unilateral liberalization, the costs of resource reallocation had already been paid, and a relatively efficient, export-oriented production sector had resulted.

Third, preferential agreements should be seen as complements to, not substitutes for, unilateral and multilateral policies. All have something to offer in terms of a country's position in the international system. Preferential agreements are often said to be second-best, but they should not be eschewed for this reason. Of course, care must be taken in the way such agreements are negotiated to avoid the "spaghetti bowl" or "noodle bowl" effects; Chile could do better on this count.

Fourth, a successful preferential initiative requires strong institutional support. Expertise about potential partners is very important, and foreign ministries have to modernize themselves 
on this dimension and with respect to economics in general. Negotiators need to be well trained, and other government agents (such as export promotion agencies) also need to play a part.

$\underline{\text { Fifth, }}$ it is crucial to recognize that trade is not an isolated part of the economy. Chile has done an excellent job in managing its macroeconomic balances, including a number of financial and fiscal innovations. It has done less well with respect to microeconomics. While some of its large firms are extremely efficient, many firms are still not well positioned for international competition. The government is aware of these problems, but it needs to put more effort into remedying them if Chile is to realize the full potential of its international trade accomplishments (see Mesquita Moreira and Blyde, 2006). 


\section{References}

Aninat, Augusto and Mercedes Botto. 2005. "The Influence of Locally Produced Research on Trade Policy Making: The Case of Chile.” Paper prepared for Global Development Network project on "Bridging Research and Policy." Washington, DC: GDN.

Aninat, Cristóbal, John Londregan, Patricio Navia, and Joaquin Vial. 2004. "Political Institutions, Policymaking Processes, and Policy Outcomes in Chile.” Unpublished paper. Washington, DC: Inter-American Development Bank.

Cabezas, Mabel. 2003. "Tratado de libre comercio entre Chile y Estados Unidos: Revisión de estudios que cuantifican su impacto." Working Paper No. 239. Santiago: Central Bank of Chile.

Chumacero, Rómulo, Rodrigo Fuentes, Rolf Luders, and Joaquín Vial. 2007. "Understanding Chilean Reforms.” In José María Fanelli, ed., Understanding Market Reforms in Latin America: Similar Reforms, Diverse Constituencies, Varied Results. New York: Palgrave.

Estevadeordal, Antoni, Dani Rodrik, Alan M. Taylor, and Andres Velasco, eds. 2004. Integrating the Americas: FTAA and Beyond. Cambridge, MA: David Rockefeller Center Series on Latin American Studies, Harvard University.

Fischer, Carl. 2007. "Chile, Japan Sign Free Trade Agreement." Chilean government web www.chileangovernment.gov.cl/index.php?option=com_content\&task=view\&id=1480\&I $\underline{\text { temid }=1}$.

Frohmann, Alicia. 2003. "Consultations and Communication with Civil Society on Trade Negotiations: Notes on the Chilean Experience." Paper prepared for seminar on "Good Practices on Social Inclusion: A Dialogue between Europe and Latin America and the Caribbean,” Milan, Interamerican Development Bank.

Hornbeck, J.F. 2003. "The U.S.-Chile Free Trade Agreement: Economic and Trade Policy Issues." Congressional Research Report for Congress. Washington, DC: CRS. http://assets.opencrs.com/rrts/RL31144_20030910.pdf.

Harrison, Glenn, Thomas Rutherford, and David Tarr. 1997. "Trade Policy Options for Chile: A Quantitative Evaluation." Policy Research Paper 1783. Washington, DC: World Bank.

. 2003. "Chile's Regional Arrangements: The Importance of Market Access and Lowering the Tariff to Six Percent." Working Paper No. 238. Santiago: Central Bank of Chile.

IMF (International Monetary Fund). 1991. Direction of Trade Statistics Yearbook, 1991. Washington, DC: IMF. . 2007. Direction of Trade Statistics Yearbook, 2007. Washington, DC: IMF. 
IRELA (Instituto de Relaciones Europeo-Latinoamericanas). 1996. Foreign Direct Investment in Latin America in the 1990s. Madrid: IRELA.

Koo, Min Gyo. 2006. "From Multilateralism to Bilateralism? A Shift in South Korea's Trade Strategy." In Vinod Aggarwal and Shujiro Urata, eds. Bilateral Trade Agreements in the Asia-Pacific: Origins, Evolution, and Implications. London: Routledge.

Malaga, Jaime and Flynn Adcock. 2004. "U.S.-Chile Free Trade Agreement: What Is There for Agriculture?" Presentation for AAEA Annual Meeting, Denver, CO. http://cnas.tamu.edu/publications/PowerPoint/MalagaAAEAChileFTA.ppt\#268,1,U S-Chile Free Trade Agreement What is there for Agriculture?

Mesquita Moreira, Mauricio and Juan Blyde. 2006. "Chile's Integration Strategy: Is There Room for Improvement?" IADB-INTAL-ITD Working Paper No. 21. Washington, DC: IADB.

Nowak-Lehmann, Felicitas, Dierk Herzer, and Sebastián Vollmer. 2005. "The Free Trade Agreement between Chile and the EU: Its Potential Impact on Chile's Export Industry." Discussion Paper 125. Ibero-American Institute for Economic Research. Gottingen, Germany: Georg-August-Universitat.

Oppenheim, Lois Hecht. 2006. "Chilean Economic Policy under the Concertacion: The Triumph of the Market?” In Silvia Borzutsky and Lois Hecht Oppenheim, eds. After Pinochet: The Chilean Road to Democracy and the Market. Gainesville: University of Florida Press.

Park, Sung-Hoon and Min Gyo Koo. 2007. "Forming a Cross-Regional Partnership: The South Korea-Chile FTA and its Implications.” Pacific Affairs 80, 2.

Porras, José Ignacio. 2003. "La estrategia chilena de acuerdos comerciales: un análisis político.” Working Paper 36. Division of Trade and Integration, UN Economic Commission for Latin America and the Caribbean. Santiago: ECLAC.

Rosales, Osvaldo. 2003. "Chile-U.S. Free Trade Agreement: Lessons and Best Practices." Paper presented to the American Chamber of Commerce, Washington, DC. . 2006. "Revisiting Chilean Integration to World Economy." Presentation for APEC Symposium on Catalytic Role of the APEC Process, Chiba, Japan.

Rosales, Osvaldo and Mikio Kuwayama. 2007. "América Latina y China e India: Hacia una nueva alianza de comercio e inversión." Working Paper 81. Division of Trade and Integration, UN Economic Commission for Latin America and the Caribbean. Santiago: ECLAC. 
Saavedra-Rivano, Neantro. 1993. "Chile and Japan: Opening Doors through Trade." In Barbara Stallings and Gabriel Szekely, eds. Japan, the United States, and Latin America: Toward a Trilateral Relationship in the Western Hemisphere. Baltimore: Johns Hopkins University Press.

Sáez, Sebastián. 2005. "Implementing Trade Policy in Latin America: The Cases of Chile and Mexico." Working Paper 54. Division of Trade and Integration, UN Economic Commission for Latin America and the Caribbean. Santiago: ECLAC.

Sáez, Sebastián and Juan Gabriel Valdés. 1999. "Chile and its 'Lateral' Trade Policy." CEPAL Review 67: 854-99.

Schiff, Maurice. "Chile's Trade and Regional Integration Policy: An Assessment." The World Economy 25: 973-90.

Schott, Jeffrey. 2001. Prospects for Free Trade in the Americas. Washington, DC: IIE.

Schuschny, Andrés, José Durán, and Carlos de Miguel. 2007. "Política commercial de Chile y los TLC con Asia: Evaluación de los efectos de los TLC con Japón y China." Paper prepared for Tenth Annual Conference on Global Economic Analysis, Purdue University, West Lafayette, IN. www.gtap.agecon.purdue.edu/resources/res_display.asp?RecordID=2354

Silva, Verónica. 2004. "Chile: A Multi-track Market Access Strategy." In Miguel Lengyel and Vivianne Ventura-Dias. Trade Policy Reforms in Latin America: Multilateral Rules and Domestic Institutions. London: Palgrave-Macmillan, pp.27-46.

Stallings, Barbara. 2007. "Integration in Latin America: Lessons for East Asia." Paper prepared for Conference on Integration in East Asia. Institute of Social Science, University of Tokyo, Tokyo, Japan.

Stefoni, Carolina and Claudio Fuentes. 1998. "Chile and Mercosur: How Far Do We Want Integration to Go?" Discussion Paper 25. Management of Social Transformations (MOST) Project. Paris: UNESCO.

Stoler, Andrew. 2006. "Regionalism v. Multilateralism: A View from the Asia-Pacific." Paper for CEPAL-BID-OBREAL Regional Integration Seminar, Santiago, Chile.

Ulloa Urrutia, Alfie Antonio. 2003. "Chile's Trade Policy and the Chile-United States Free Trade Agreement." http://www1.lanic.utexas.edu/project/asce/pdfs/volume13/ulloafta.pdf

World Bank. 2007. World Development Indicators, 2007. Washington, DC: World Bank. 
$\underline{\text { Websites }}$

Chilean Directorate of International Economic Affairs, Ministry of Foreign Affairs: www.direcon.cl

Chilean Government: www.chileangovernment.gov.cl

Chilean Foreign Investment Committee: www.foreigninvestment.cl

Organization of American States, Foreign Trade Information System: www.sice.oas.org 
Table 1. Characteristics of Chilean PTAs and Partners

\begin{tabular}{|c|c|c|c|c|c|c|c|c|}
\hline Country & Year $^{\mathrm{C}}$ & Share of Trade ${ }^{\mathrm{e}}$ & Share of FDI Stock ${ }^{f}$ & Investment & Services & $\begin{array}{l}\text { Issue Scope } \\
\text { Environment }\end{array}$ & Labor & Econ Coop \\
\hline Mexico & $1991 / 1998^{d}$ & $0.79 / 4.03$ & $0.1 / 0.3$ & $0 / X$ & $0 / X$ & $0 / 0$ & $0 / 0$ & $\mathrm{X} / 0$ \\
\hline Bolivia & 1993 & 0.46 & n.a. & 0 & 0 & 0 & 0 & $X$ \\
\hline Venezuela & 1993 & 2.24 & 0.1 & 0 & 0 & 0 & 0 & $x$ \\
\hline Colombia & $1994 / 2006^{d}$ & $1.01 / 0.96$ & 0.3 & $0 / X$ & $0 / X$ & $0 / X$ & $0 / X$ & $0 / X$ \\
\hline Ecuador & 1994 & 1.16 & 0 & 0 & 0 & 0 & 0 & $x$ \\
\hline Mercosur $^{\mathrm{a}}$ & 1996 & 13.91 & 3.2 & 0 & 0 & 0 & 0 & $x$ \\
\hline Canada & 1996 & 1.28 & 12.9 & $x$ & $x$ & $X^{h}$ & $X^{h}$ & 0 \\
\hline Peru & $1998 / 2006^{d}$ & $1.30 / 2.55$ & 0 & $0 / X$ & $0 / X$ & $0 / 0$ & $0 / 0$ & $\mathrm{X} / 0$ \\
\hline Costa Rica & 1999 & 0.14 & n.a. & $x$ & $x$ & 0 & 0 & 0 \\
\hline El Salvador & 1999 & 0.03 & n.a. & $x$ & $x$ & 0 & 0 & 0 \\
\hline European Union & 2002 & 21.21 & 19 & $x$ & $x$ & 0 & 0 & $x$ \\
\hline EFTA & 2003 & 0.84 & 2.5 & 0 & $x$ & 0 & 0 & 0 \\
\hline United States & 2003 & 17.03 & 41.5 & $X$ & $X$ & $X$ & $X$ & 0 \\
\hline Korea & 2003 & 3.27 & n.a. & $x$ & $x$ & 0 & 0 & 0 \\
\hline China & 2005 & 0.84 & n.a. & $0^{9}$ & $0^{g}$ & 0 & 0 & $x$ \\
\hline$P-4^{b}$ & 2005 & 8.82 & n.a. & $0^{g}$ & $x$ & $x^{h}$ & $x^{h}$ & $x$ \\
\hline India & 2006 & 0.24 & n.a. & 0 & 0 & 0 & 0 & 0 \\
\hline Japan & 2007 & 7.71 & 3.1 & $X$ & $x$ & 0 & 0 & 0 \\
\hline
\end{tabular}

Sources: IMF, Direction of Trade Yearbook for trade; IRELA (1996) for FDI; trade agreements for year and scope.

a Argentina, Brazil, Paraguay, Uruguay.

${ }^{\mathrm{b}}$ Brunei, Chile, New Zealand, Singapore.

${ }^{\mathrm{c}}$ Year agreement entered into force.

${ }^{d}$ Upgraded from Economic Complementation Agreement to FTA; in effect for Mexico; signed but not ratified for Colombia and Peru.

${ }^{\mathrm{e}}$ For year prior to entry into force of agreement.

${ }^{f}$ For year nearest to agreement from available data.

${ }^{g}$ Follow-up negotiations underway.

${ }^{\mathrm{h}}$ Side agreements. 
Table 2. Comparative Statistics for Chile and Major PTA Partners, 2005

\begin{tabular}{|c|c|c|c|c|c|c|}
\hline Country & $\begin{array}{r}\text { Population } \\
\text { (millions) } \\
\end{array}$ & $\begin{array}{r}\text { GDP } \\
\text { (\$ billions) } \\
\end{array}$ & $\begin{array}{r}\text { GDP per } \\
\text { capita } \\
\end{array}$ & $\begin{array}{r}\text { Exports* } \\
\text { (\$ billions) } \\
\end{array}$ & $\begin{array}{r}\text { Exports* } \\
\text { (\% of GDP) } \\
\end{array}$ & $\begin{array}{r}\text { Exp growth }{ }^{\star \star} \\
1990-2005 \\
\end{array}$ \\
\hline Chile & 16 & 96 & 5870 & 41 & 42 & $\overline{8.2}$ \\
\hline Brazil & 186 & 662 & 3550 & 118 & 17 & 7.5 \\
\hline Argentina & 39 & 173 & 4470 & 40 & 25 & 7.9 \\
\hline Peru & 28 & 74 & 2650 & 17 & 25 & 8.9 \\
\hline Mexico & 103 & 753 & 7310 & 214 & 30 & 12.9 \\
\hline US & 296 & 12913 & 43560 & 904 & 10 & 5.2 \\
\hline EU & 314 & 10075 & 32098 & 3113 & 37 & na \\
\hline Japan & 128 & 4977 & 38950 & 595 & 13 & 13.7 \\
\hline Korea & 22 & 765 & 15840 & 284 & 43 & 15.5 \\
\hline China & 1305 & 2270 & 1740 & 1054 & 38 & 15.4 \\
\hline
\end{tabular}

Source: World Bank (2007).

* Exports of goods and services.

** Exports of goods only. 
Table 3. Impact of Chile's Bilateral and Plurilateral Trade Agreements, 1992-2007

\begin{tabular}{clcc}
\hline Year & Partner(s) & \% of imports liberalized & Effective tariff \\
\hline \multirow{2}{*}{$1992-93$} & Mexico & 4.2 & 10.5 \\
& Venezuela & & \\
& Bolivia & & \\
& Colombia & & 9.9 \\
1995 & Ecuador & 7.7 & 8.8 \\
1996 & Mercosur & 23.2 & 8.6 \\
1997 & Canada & 26.0 & 8.6 \\
1998 & Peru & 26.2 & 4.7 \\
2002 & Costa Rica & 37.3 & 2.9 \\
2003 & El Salvador & & 2.1 \\
2004 & EU & 56.2 & \\
& United States & 76.4 & 1.0 \\
2006 & Korea & & \\
& EFTA & 84.2 & 0.8 \\
\hline
\end{tabular}

Source: Schuschny, Duran, and de Miguel (2007), p.10. 
Figure 1. Phases of Chilean Trade Policy, 1973-2003

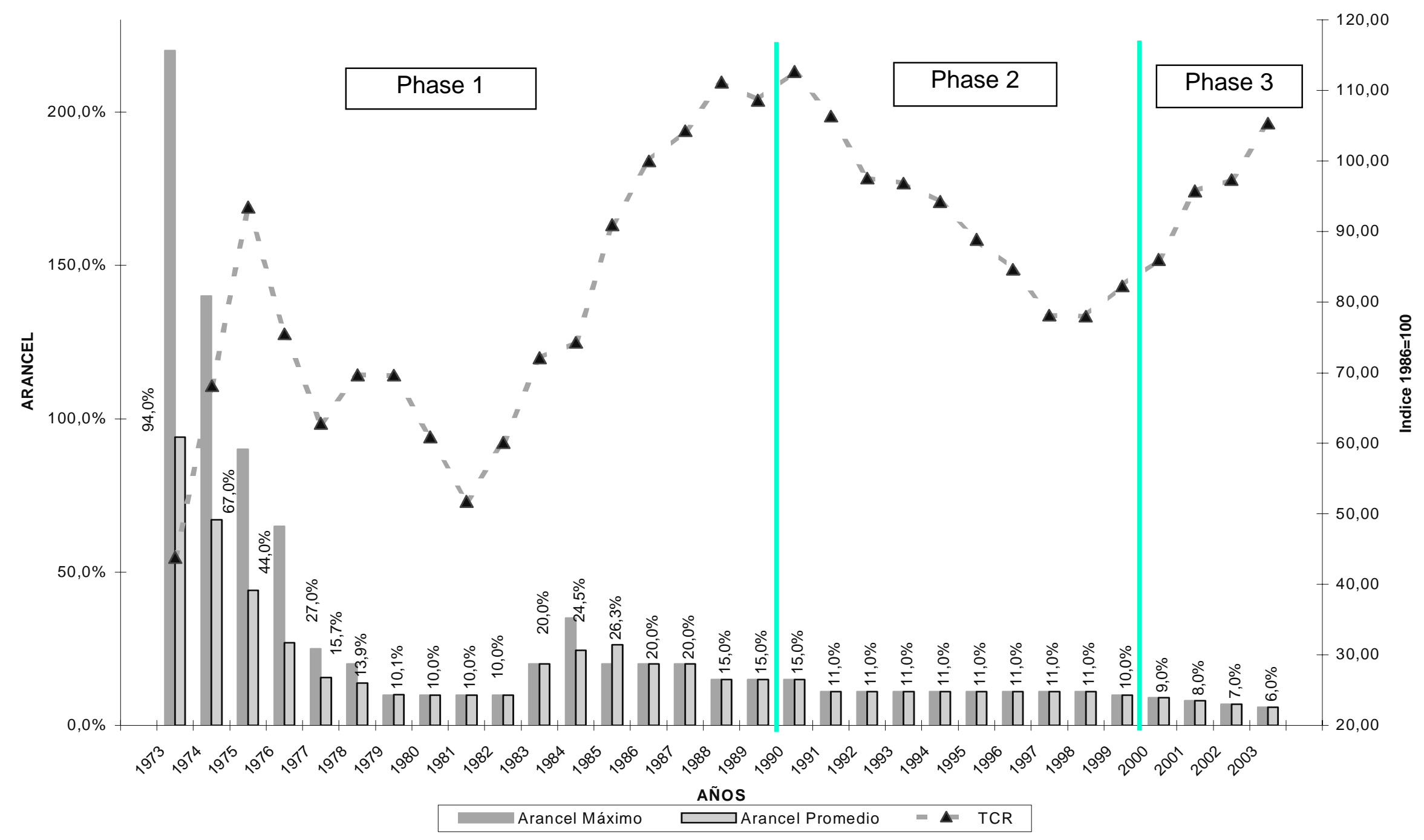


Figure 2a. Chilean Exports and Imports of Goods and Services, 1975-2006 (\$ billions)

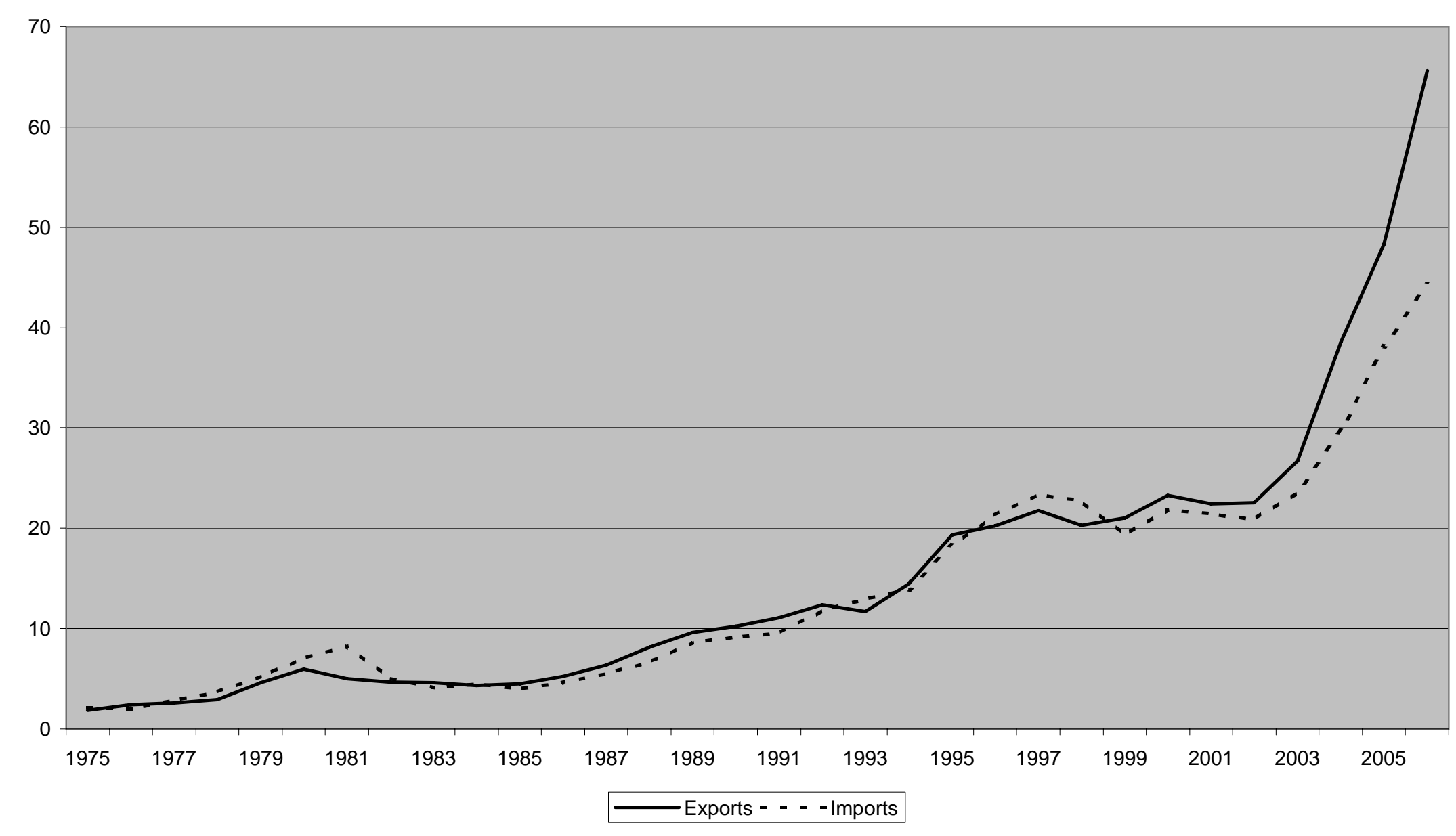


Figure 2b. Chilean Exports and Imports of Goods and Services, 1973-2005 (\% of GDP)

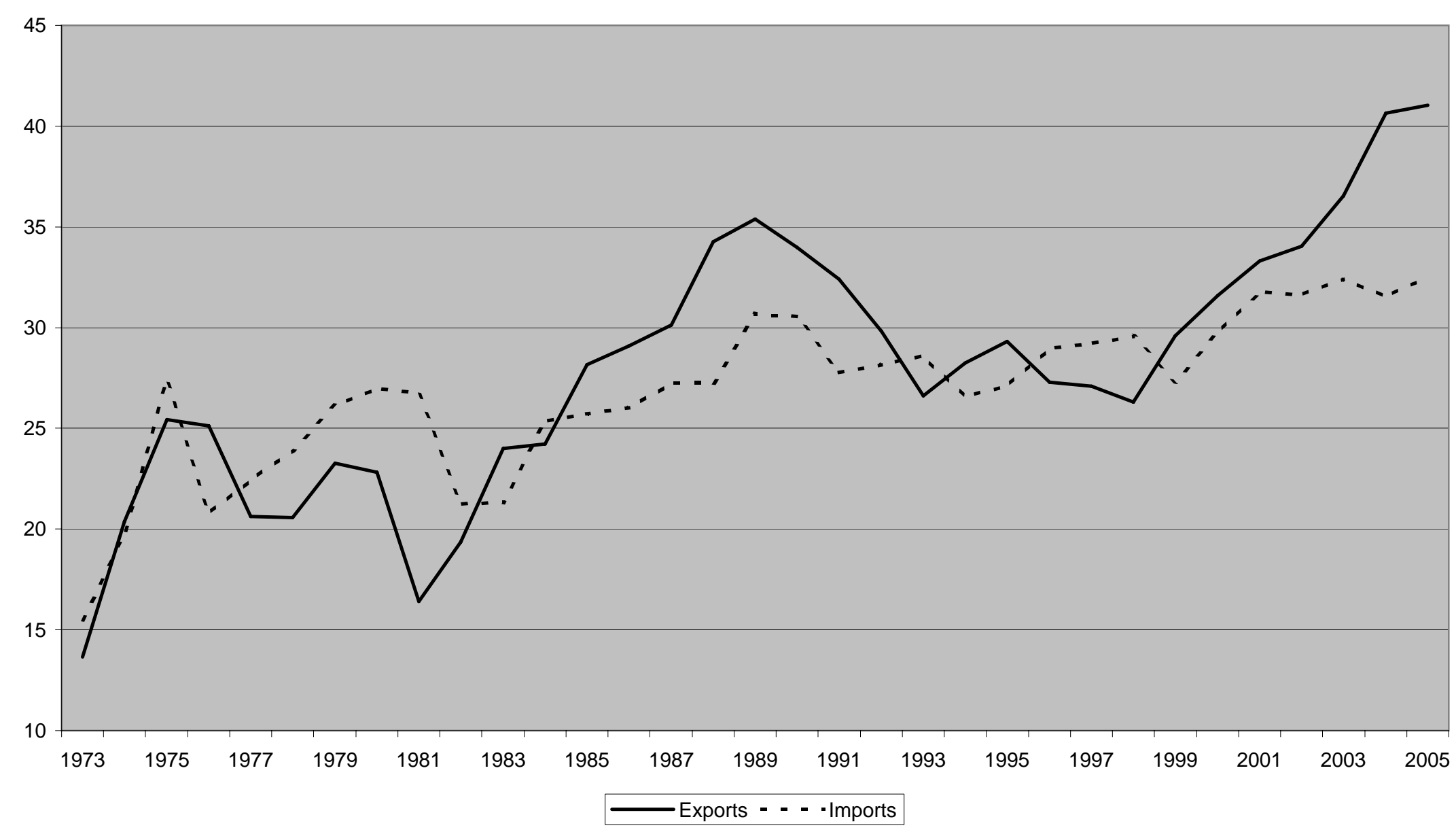


GIARI Working Paper Vol. 2008-E-11,

June.30 2008

Published by Waseda University Global COE Program

Global Institute for Asian Regional Integration (GIARI),

Waseda University, Nishiwaseda Bldg. 5F\#507 1-21-1

Nishi-waseda, Shinjuku-ku, Tokyo 169-0051 Japan

E-mail: affairs@,waseda-giari.jp

Webpage: http://www.waseda-giari.jp

Printed in Japan by International Academic Printing Co.Ltd 